\title{
Fine grained compositional analysis of Port Everglades Inlet microbiome using high throughput DNA sequencing
}

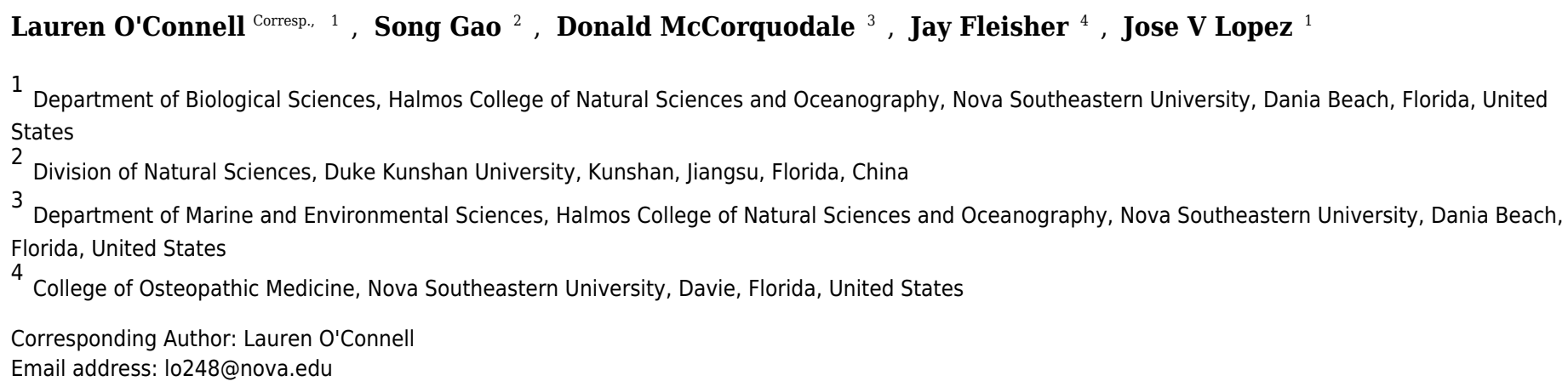

Background. Similar to natural rivers, manmade inlets connect inland runoff to the ocean. Port Everglades Inlet (PEI) is a busy cargo and cruise ship port in South Florida, which can act as a source of pollution to surrounding beaches and offshore coral reefs. Understanding the composition and fluctuations of bacterioplankton communities ("microbiomes") in major port inlets is important due to potential impacts on surrounding environments. We hypothesize seasonal microbial fluctuations, which were profiled by high throughput 16S rRNA amplicon sequencing and analysis. Methods $\boldsymbol{\&}$ Results. Surface water samples were collected every week for one year. A total of 4 samples per month, 2 from each sampling location, were used for statistical analysis creating a high sampling frequency and finer sampling scale than previous inlet microbiome studies. We observed significant differences in community alpha diversity between months and seasons. Analysis of composition of microbiomes (ANCOM) tests were run in QIIME 2 at genus level taxonomic classification to determine which genera were differentially abundant between seasons and months. Beta diversity results yielded significant differences in PEI community composition in regard to month, season, water temperature, and salinity. Analysis of potentially pathogenic genera showed presence of Staphylococcus and Streptococcus. However, statistical analysis indicated that these organisms were not present in significantly high abundances throughout the year or between seasons.

Discussion. Significant differences in alpha diversity were observed when comparing microbial communities with respect to time. This observation stems from the high community evenness and low community richness in August. This indicates that only a few organisms dominated the community during this month. August had lower than average rainfall levels for a wet season, which may have contributed to less runoff, and fewer bacterial groups introduced into the port surface waters. Bacterioplankton beta diversity 
differed significantly by month, season, water temperature, and salinity. The 2013-2014 dry season (October-April), was warmer and wetter than historical averages. This may have driven significant differences in beta diversity. Increased nitrogen and phosphorous concentrations were observed in these dry season months, possibly creating favorable bacterial growth conditions. Potentially pathogenic genera were present in the PEI. However their relatively low, non-significant abundance levels highlight their relatively low risk for public health concerns. This study represents the first to sample a large port at this sampling scale and sequencing depth. These data can help establish the inlet microbial community baseline and supplement the vital monitoring of local marine and recreational environments, all the more poignant in context of local reef disease outbreaks and worldwide coral reef collapse in wake of a harsh 2014-16 El Niño event. 


\section{Fine-Grained Compositional Analysis of Port Everglades Inlet Microbiome Using High}

\section{Throughput DNA Sequencing}

3

4 Lauren M. O’Connel1 ${ }^{1,3}$, Song Gao ${ }^{2}$, Donald McCorquodale ${ }^{3}$, Jay Fleisher ${ }^{4}$, Jose V. Lopez ${ }^{1}$

5

$6{ }^{1}$ Department of Biological Sciences, Halmos College of Natural Sciences and Oceanography,

7 Nova Southeastern University, Dania Beach, FL, USA

8 2Division of Natural Sciences, Duke Kunshan University, Kunshan, Jiangsu, China

$9{ }^{3}$ Department of Marine and Environmental Sciences, Halmos College of Natural Sciences and

10 Oceanography, Nova Southeastern University, Dania Beach, Florida, USA

$11{ }^{4}$ College of Osteopathic Medicine, Nova Southeastern University, Davie, Florida, USA

12

13 Corresponding Author:

14 Lauren O'Connell ${ }^{1}$

15 Locon833@gmail.com 


\section{Abstract}

25 Background. Similar to natural rivers, manmade inlets connect inland runoff to the ocean. Port

26 Everglades Inlet (PEI) is a busy cargo and cruise ship port in South Florida, which can act as a

27 source of pollution to surrounding beaches and offshore coral reefs. Understanding the composition and fluctuations of bacterioplankton communities ("microbiomes") in major port inlets is important due to potential impacts on surrounding environments. We hypothesize seasonal microbial fluctuations, which were profiled by high throughput $16 \mathrm{~S}$ rRNA amplicon sequencing and analysis. Methods \& Results. Surface water samples were collected every week for one year. A total of 4 samples per month, 2 from each sampling location, were used for statistical analysis creating a high sampling frequency and finer sampling scale than previous inlet microbiome studies. We observed significant differences in community alpha diversity between months and seasons. Analysis of composition of microbiomes (ANCOM) tests were run in QIIME 2 at genus level taxonomic classification to determine which genera were differentially abundant between seasons and months. Beta diversity results yielded significant differences in PEI community composition in regard to month, season, water temperature, and salinity.

Analysis of potentially pathogenic genera showed presence of Staphylococcus and

Streptococcus. However, statistical analysis indicated that these organisms were not present in

41 significantly high abundances throughout the year or between seasons. Discussion. Significant differences in alpha diversity were observed when comparing microbial communities with respect to time. This observation stems from the high community evenness and low community

44 richness in August. This indicates that only a few organisms dominated the community during this month. August had lower than average rainfall levels for a wet season, which may have contributed to less runoff, and fewer bacterial groups introduced into the port surface waters. 
47 Bacterioplankton beta diversity differed significantly by month, season, water temperature, and

48 salinity. The 2013-2014 dry season (October-April), was warmer and wetter than historical

49 averages. This may have driven significant differences in beta diversity. Increased nitrogen and

50 phosphorous concentrations were observed in these dry season months, possibly creating

51 favorable bacterial growth conditions. Potentially pathogenic genera were present in the PEI.

52 However their relatively low, non-significant abundance levels highlight their relatively low risk

53 for public health concerns. This study represents the first to sample a large port at this sampling

54 scale and sequencing depth. These data can help establish the inlet microbial community baseline

55 and supplement the vital monitoring of local marine and recreational environments, all the more

56 poignant in context of local reef disease outbreaks and worldwide coral reef collapse in wake of

57 a harsh 2014-16 El Niño event. 


\section{Introduction}

A continental coastal zone can represent a gradient across distinct biogeographical

74 boundaries (freshwater, brackish and saltwater). Mangroves, streams, or manmade inlets in these

75 transition zones provide potential links. Fort Lauderdale's Port Everglades Inlet (PEI) (also

76

77

78 known as the Port Everglades Shipping Channel [PESC]), in Broward County, FL is a manmade, dredged, deep-water port located along the southeastern coast of subtropical Florida (Stauble 1993; http://www.porteverglades.net; NOS, 2011). Located directly offshore from the PEI is a major US coral reef tract (Staley et al., 2017), as well as multiple recreational beaches, fishing piers, and watersport areas (Stamates et al., 2013). Coral reefs, beaches, and recreational water sport areas are impacted both positively and negatively by resident microbial communities of these areas. The ecosystem services of bacteria in marine communities include nutrient cycling and symbiosis, while disadvantages include the possible presence of marine pathogens, which may cause illness in the marine environment or to humans utilizing it.

Although large-scale bacterioplankton community (or "microbiome") studies such as the Tara expeditions or the Earth Microbiome project, have their place providing important global information on a diverse array of marine microbial habitats (Sunagawa et al, 2015; Thompson et al, 2017), much value can also be obtained by focusing on finer scale microbial dynamics of distinct local habitats especially when unique. PEI is one of largest cargo and cruise ship ports in the country and is susceptible to pollution and pathogens from cargo and cruise ships via ballast water flushing, oil leakage, and cargo spills, and through land-based pollution. The past decade has marked rapid increases in human population and coastal development, resulting in the input 
93 of human pathogens and enteric bacteria into coastal waters (Mallin et al., 2000; Lapointe et al.,

94 2015). The introduction of these pathogens can cause human illnesses such as skin, ear, and

95 gastric infections and can cause disease in marine organisms. This was seen with the introduction

96 of the human pathogen Serratia marcescens, into a coral reef ecosystem, which was found to be

97 the causative agent in the bleaching event seen in the Carribbean elkhorn coral (Sutherland et al.,

98 2011). Pollution into PEI also occurs via land-based runoff. Land-based runoff contributes to

99 nutrient, pathogen, and pollutant deposition into the marine environment, which can lead to

100 eutrophication (Carrie Futch et al., 2011; Lapointe et al., 2015; Staley et al, 2017).

101 Eutrophication leads to conditions of hypoxia and anoxia and decreased biodiversity causing

102 major shifts in community structure of an ecosystem. These shifts can result in an increase of

103 phytoplankton, which can cause harmful algal blooms, and can eventually lead to reduction of

104 zooplankton and bacterioplankton diversity (Marcus 2004; Paerl et al., 2003). Southern Florida

105 has two main seasons. The wet season mostly ranges from May-September, while the dry season

106 occurs from October-April. The wet season is mostly during the hot summer months, and is

107 characterized by increased rainfall levels and increased temperatures. With increased rainfall

108 levels, also comes increased runoff into the marine environment. Previous research has indicated

109 that influxes of nutrients from agriculture practices in near-shore environments are contributing

110 to degradation of Florida reef ecosystems via eutrophication and introduction of pathogens (Finkl

111 and Charlier, 2003; Banks et al., 2008; Walker et al., 2008; Lewis et al., 2017).

112 This study reports an extensive environmental next-generation sequencing

113 characterization of the bacterioplankton microbiome from the surface seawater in PEI. Water

114 samples were collected from June 2013 to May 2014 to determine monthly and seasonal alpha

$115(\alpha)$ and beta $(\beta)$ diversity fluctuations. Fluctuations of the bacterioplankton community in PEI's 
116 surface water was monitored over a year. While samples were collected weekly, a total of 4

117 samples per month, 2 from each location in the port, were used for consistency in statistical

118 analyses. This study provides a higher sampling resolution than has been currently reported. To

119 date, inlet study data has been collected bi-monthly, quarterly, and for a shorter sampling periods

120 (Wallace et al. 2018; Staley et al. 2017; Campbell et al. 2015).

121 The primary hypothesis of this study predicted strong seasonal effects on the inlet

122 microbiome in PEI due to temperature and rainfall. It was also hypothesized that potentially

123 harmful pathogens to both humans would be present in a higher abundance during the wet

124 season.

125 This study applied high-throughput (HTP) sequencing technology to complete DNA

126 sequencing of surface seawater samples in PEI, extending from previous inlet studies, which

127 were largely restricted to a smaller sample sizes, lower sampling frequency, and culture-based or

128 RT-qPCR methods (Symonds et al., 2016; Aranda et al., 2015; Campbell et al., 2015).

\section{Materials \& Methods}

131 Water Sample Collection, DNA Extraction, and Chemical Analysis. A total of 151

132 surface seawater samples were collected weekly, at ebb tide, from PEI in Broward County, FL

133 by kayak over a year-long timespan (June 2013- July 2014). Three 1.0 liter water samples were

134 collected at a depth of 0.5 meters every week from two different sites within in the inlet. Water

135 temperature was measured in situ at time of sampling with a glass thermometer. Salinity

136 measurements were taking immediately upon returning to lab (within 30 minutes of sample

137 collection) with a refractometer. Precipitation values were obtained using NOAAs data from the

138 National Center for Environmental Information (http://www.ncdc.noaa.gov/cag/time-series). For 
139 each site, $1.0 \mathrm{~L}$ of water was filtered using Pall GN Metricel ${ }^{\circledR}$ grid $47 \mathrm{~mm}, 0.45 \mu \mathrm{m}$ filters, by

140 vacuum filtration.

141 Total microbial genomic DNA was extracted using MO BIO’s PowerLyzer ${ }^{\mathrm{TM}}$

142 PowerSoil $^{\circledR}$ kit (Carlsbad,CA). Genomic DNA size and quality was verified with a 1\% agarose

143 gel and Nanodrop measurements. A total of 81 samples were queued for sequencing based on

144 quality of extracted DNA. Samples that showed clear, non-degraded, high molecular weight

145 genomic DNA bands and had 260/280 ratios $\sim 1.8$ were considered quality DNA. After gel

146 verification, DNA concentration was measured using the Qubit 2.0 (Life Technologies).

147 Surface water samples collected at each site were subjected to ion chromatography (IC)

148 analysis using a Thermo Scientific Dionex ICS-1600 system (Bannockburn, IL). After filtration

149 of particulates using syringe filters, samples were diluted 1000 times before injection into the IC.

150 Ion chromatography analysis was used to detect the presence and measure the concentrations of

151 chemical ions in the PEI surface water. A total of five anions - fluoride, chloride, nitrate,

152 phosphate, and sulfate - were analyzed with calibration curves from standard solutions and

153 detection limits at approximately $10 \mathrm{ppb}$.

154 Sequencing Sample Preparation. Samples were prepared for MiSeq ${ }^{\circledR}$ sequencing

155 following Illumina's 16S Metagenomic Sequencing Library Preparation guide (Illumina, 2013).

156 The amplicon primers used for the first PCR were universal primers, MIDf-515F and 806rc

157 which amplified the V4 region of the 16S rRNA gene (Caporaso et al., 2010). Illumina adaptor

158 sequences were added to these primers as outlined in the aforementioned Metagenomic

159 Sequencing Library Preparation Guide (Illumina, 2013). A second PCR was completed to attach

160 Illumina Nextera indices using the Illumina Nextera indexing kit so that samples could be 
161 demultiplexed (Illumina, 2013). The final pooled DNA library was diluted to a concentration of

$1624 \mathrm{pM}$ with a $50 \%$ spike in of $12.5 \mathrm{pM} \mathrm{PhiX}$.

163 Sequence Analyses. Sequence analysis was performed using Quantitative Insights into

164 Microbial Ecology 2 (QIIME2) (Caporaso et al., 2010a). Paired ends were joined using

165 PANDAseq 2.8 .1 at a 90\% confidence level (Masella et al, 2012). A total of 4 samples per

166 month, 2 from each location, resulting in a total of 48 samples were used for downstream

167 analysis so as not to skew statistical analysis. Paired end sequences were imported into QIIME2

168 and sequence quality control was completed using the DADA2 pipeline incorporated into

169 QIIME. The DADA2 program filtered out phiX reads, removed chimeric sequences, and

170 assigned reads into Operational Taxonomic Units (OTUs). The sequences were truncated to 220

171 basepairs because the quality of reverse reads after base 220 declined. OTUs were grouped into

172 clusters at 97\% sequence similarity (Callahan et al., 2016). Taxonomy was assigned using the

173 DADA2 pipeline which implemented the Ribosomal Database Project (RDP) naïve Bayesian

174 classifier (Callahan et al., 2016).

175 Statistical Analyses. All statistical analyses were completed using QIIME2 and R Statistical

176 Software Version 1.1.383. The R package phyloseq was used to generate stacked bar charts

177 depicting relative abundance of taxa (McMurdie and Holmes, 2013). Richness and evenness

178 estimates were calculated using QIIME2 (https://qiime2.org). To determine statistical

179 significance in alpha diversity non-parametric Kruskal-Wallis tests using Pielou's evenness

180 values were used to complete pairwise comparisons between month, location, and weather at

181 time of sampling (rain vs. no rain). Non-parametric Kruskal-Wallis comparisons were performed

182 using Faith's Phylogenetic Diversity to determine if there were statistical differences in species

183 richness in the PEI samples. Box and whisker plots for species richness and evenness were 
184 generated using QIIME2. To test non-discrete metadata (salinity and water temperature) for

185 correlations with alpha diversity, Spearman's Rank correlation analysis was completed using

186 Pielou's evenness values. Taxonomic stacked bar charts were generated using data from QIIME2

187 imported into Phyloseq. Analysis of composition of microbiomes (ANCOM) test were run to

188 determine if there were significant differences in the relative abundance of any taxa between

189 month or season (Mandal et al. 2015).

190 Statistical analyses for beta diversity were completed by calculating Bray-Curtis distance

191 using QIIME2. A PERMANOVA was run to complete pairwise comparisons of samples for

192 month, location, and season. Principle Coordinate Analysis (PCoA) plots were generated for

193 month sample taken and for season from Bray-Curtis distances using QIIME2. A Mantel test was

194 run to determine if there were statistically significant correlations in beta diversity in relation to

195 non-discrete metadata.

196 Regression Analysis. A series of Multiple Least Squares Regressions were used to assess

197 possible relationships between each bacterial class and the environmental variables taken as part

198 of the study. The $\mathrm{R}^{2}$ value is the measure used to determine how well the data fits the regression

199 line. The higher $\mathrm{R}^{2}$ values indicated better data fits with the model. The class level taxonomic

200 classification was used to evaluate relationships between environmental variables because

201 majority of the sequences were classified to the class level. A backward selection method was

202 used with both entry and model retention. All regression analyses were carried out using SAS

203 Statistical Software (SAS Institute).

204 Potential Pathogen Detection. Potentially pathogenic bacteria were detected by filtering

205 out genera that may be pathogenic. Statistical analysis was completed on Staphylococcus and

206 Streptococcus spp. using the ANCOM test. This test compares abundances of genera to 
207 determine if they change significantly between populations or environments (Mandal et al.,

208 2015). To display presence of potential pathogens graphically, the relative abundance, genus, and

209 month were plotted and faceted by season using the plot_bar command in phyloseq.

\section{Results}

211 16S rRNA Sequence Output Overview. A total of 151 samples were collected weekly from

212 PEI from July 2013-June 2014; among them 81 samples were queued for DNA sequencing. A

213 total of 48 samples, 4 per month, 2 from each site, were used for downstream bioinformatics

214 analysis (Table S1). The MiSeq sequencing yielded a total of 1,435,072 raw sequences with Q

215 scores greater than 30 and an average read length of 255 basepairs. The average number of reads

216 per sample was 20,586 with the minimum number of reads per sample being 9,199 and the

217 maximum number of reads per sample being 35,108 . A total of 25,020 chimeric sequences were

218 removed from the dataset with a total of $1,410,052$ sequences left for OTU table generation and

219 database alignment. After filtering of sequences to remove identical sequences and subsequences

220 a total of 395,009 unique sequences were left for taxonomic assignment using the Greengenes

$221 \quad 13 \_8$ database. A total of 16,384 OTUs were generated.

222 Alpha Diversity. Alpha diversity was assessed through species evenness and species richness

223 measures. Results for species evenness were statistically significant for month and season

$224(\mathrm{p}=0.015 ; \mathrm{p}=0.020$ respectively). There were no significant differences in species evenness for

225 PEI samples by location, or weather at time of sampling (raining vs. not raining) ( $p>0.05$ ). The

226 month of August had the lowest species evenness values indicating that these samples were

227 dominated only by a few organisms. The month of December had the highest level of species

228 evenness (Fig. S1). The wet season has lower species evenness values than the dry season (Fig. 
229 1). In contrast, no significant differences in alpha diversity appeared in relation to water

230 temperature or salinity $(\mathrm{p}>0.05)$.

231 Statistically significant differences were seen in species richness in relation to month and

232 season ( $p=0.010 ; p=0.025$ respectively). For example, the month of December had the lowest

233 measure of species richness, while September had the highest measure of species richness (Fig.

234 S2). Concordantly, the wet season samples had higher species richness values than the dry

235 season (Fig. 1). In contrast, species richness analyses across samples indicated that there were no

236 statistically significant differences in species richness in relation to rain at time of sampling

237 versus no rain at time of sampling, water temperature values, salinity measures, or sampling

238 location $(\mathrm{p}>0.05)$.

239 Beta Diversity. The PEI samples were analyzed to determine if there were significant

240 differences in the microbial communities due to differences in sampling location, month that the

241 sample was taken, season, weather at time of sampling, salinity, and water temperature.

242 Location. The results of the PERMANOVA test using Bray-Curtis dissimilarity

243 indicated no significant differences in beta diversity of samples taken at two different locations

244 in PEI $(\mathrm{p}=0.99)$.

Weather at Time of Sampling (Raining vs. Not Raining). There were significant

246 differences in beta diversity of PEI samples in regards to weather (rain vs. no rain) at the time of

247 sampling $(\mathrm{p}=0.03)$.

Season. Results of the PERMANOVA indicated that there were significant differences in

249 the microbial community composition between seasons $(\mathrm{p}=0.001)$ There is separation of points

250 in the PCoA plot between the wet and dry seasons, displaying that there are differences in the

251 microbial community composition (Fig. 2). 

that there were overall significant differences observed in the beta diversity of all months tested $(p=0.001)$. Multiple pairwise comparisons were completed to determine which months differed significantly from one another. All months differed significantly in beta diversity except for

257 October, and July and June (Table S2).

258 Abundant Genera. To better understand how the microbial community composition fluctuated with season we examined which organisms were present at different taxonomic levels and their relative abundance levels. Proteobacteria, Planctomycetes, Cyanobacteria, Bacteroidetes, Actinobacteria, Verrucomicrobia, Tenericutes, and Euryarchaeota were the most abundant phyla across all samples, with Proteobacteria making up at least $25 \%$ of the bacterial community in all samples (Fig. S3). At the lower taxonomic levels, an increased number of taxa were observed in wet season in comparison to the dry season (13 vs 11 taxa) (Fig. 3). While observable fluctuations in relative abundance levels are seen in the Opitutus and Anaerospora genera, results from the ANCOM tests indicated that at the genus level, only Synechococcus differed significantly in its abundance levels from the dry to the wet season. Synechococcus spp. went through large increases in abundance levels from the dry season to the wet season (Table 1). Linear Regression Analysis with Chemical and Environmental Metadata. Multiple least Squares regression analysis results showed that there were statistically significant relationships

271 between certain taxa and salinity measures, chloride ion concentration, water temperature, sulfate 272 ion concentration, and rainfall (Table 2). An interesting trend to point out seen in the data was 273 that Proteobacteria and Cyanobacteria showed an inverse trend in abundance, which correlated 274 with temperature and rainfall data to some degree (Fig. S4). Environmental metadata for average 
275 precipitation levels and temperature was obtained through NOAA National Centers for

276 Environmental information (http://www.ncdc.noaa.gov/cag/). Rainfall averages for the month of

277 August were 3.4 inches lower than average historical data. The remaining wet season months

278 (May-October) generally had higher than average rainfall levels (Fig. 4). The average

279 temperature during the wet season months was generally higher than the historical average, while

280 the winter months had lower than average temperatures in comparison to historical data (Fig. 4).

281 Potentially Pathogenic Bacteria. Results of the ANCOM tests demonstrated that there were no

282 significant differences in the relative abundance levels of potential pathogens during the year

283 (Table S3; Table S4). In the Bacillales, Clostridiales, and Lactobacillales orders, the most

284 abundant potentially pathogenic genera were Staphylococcus and Streptococcus. Staphylococcus

285 was in highest relative abundance during the summer months of July and August, though this

286 increase in abundance was not statistically significant (Fig. 5). Staphylococcus was also present

287 during April and March, but this increase in abundance was not statistically significant.

288 Streptococcus was present in much lower abundance than Staphylococcus sp. It was present in its

289 highest abundance in April and was too low to be detected in other months. This increase in

290 abundance was not statistically significant (Fig. 5).

291 Discussion

292 Inlets are not rivers, but both share several similarities: large volumes of water flowing

293 out of them; connection of inland city and agriculture runoff with the ocean; and generation of

294 visible plumes distinct from offshore marine waters. However, as a mostly artificial construction,

295 inlets may be subject to more detailed or controlled characterizations. Our study considered that

296 different water masses (shallow and deeper) may be generated during ebb tides, which can lead

297 to hydrodynamic complexity (Stamates et al., 2013). For example, the mean volume of ebb tide 
298 surface water flow (4.41 million cubic meters per tidal phase) through the PEI is about half the

299 water flow of the deep channel. Although our sampling site was slightly outside the Intracoastal

300 waterway (ICW), we expected our water samples to more closely resemble a brackish surface

301 water microbial community rather than an open ocean water microbial community. This was

302 expected as PEI is influenced by human development and is subject to land-based pollution,

303 which does not influence open-ocean waters. Beach samples and oceanic samples would need to

304 be collected and compared to see which of these environments the inlet most resembles. In a

305 study by Miller and colleagues (2016), it was found that dredging of the Port of Miami from late

3062013 to early 2015 increased coral tissue loss on adjacent reefs due to sedimentation. The

307 dredging in the Port of Miami appears to have exacerbated local environmental stress due to the

308 coincidence with increased water temperatures leading to a mass bleaching event and increases

309 in reef disease (Miller et al., 2016). This points to the utility of the present report as a baseline

310 prior to the PEI dredging slated to occur in the near future.

311 An earlier study from our laboratory (Campbell et al., 2015) utilized high-throughput

312 454-pyrosequencing technology to generate baseline knowledge of PEI microbiomes, but this

313 was limited to sampling quarterly. In the current study multiple samples per month were

314 analyzed to assess variation and generate a more complete baseline of the microbial community

315 present in PEI. Utilization of Illumina MiSeq sequencing technology also provided more reads

316 per sample, and therefore more coverage, adding confidence to taxonomic assignments. Both

317 studies on the PEI microbiome yielded complementary data creating a strong baseline of the

318 microbiome present in the inlet. These studies can be used by local county and public health

319 officials, who conduct routine monitoring on port waters, and by environmental scientists 
320 looking to see what the impacts of the microbial community in PEI might have on the

321 surrounding coastal beaches and the adjacent Florida coral reef (Aranda et al, 2015).

323 and Season. Seasonal and monthly diversity fluctuations were observed for the PEI samples.

324 The dry season had much higher species evenness, but lower species richness when compared to

325 the wet season. This means that the communities in the dry season were dominated by a few

326 organisms in relatively equal abundances, while during the wet season more taxa were present,

327 but not in similar abundances. This was not unexpected. The wet season in Florida is

328 characterized by increased rainfall that can result in more runoff into the inlet. August had the

329 lowest levels of species evenness and average levels of species richness. August also

330 significantly differed in its microbial community composition when compared to July and

331 September, which did not differ significantly in their bacterioplankton composition. The lower

332 than average rainfall levels in August may have led to decreased sample diversity. Beta diversity

333 of PEI samples was examined and showed that community composition fluctuations were seen

334 between months, seasons, weather at time of sampling, and that there were strong correlations

335 between fluctuations in community composition relating to salinity levels and water temperature.

336 The difference in beta diversity due to weather at time of sampling (rain vs. no rain) was most

337 likely due to surface water dilution during sampling resulting in fewer bacterioplankton

338 organisms sampled during times with rain. Taxonomic classification of sequences at the phylum

339 level yielded similar bacterioplankton community composition results to previously completed

340 coastal seawater studies (Campbell et al., 2015; Gifford et al., 2014; Elifantz et al., 2013; Rappe

341 et al., 2000). The most evident microbial abundance shifts are seen at lower taxonomic levels.

342 Interestingly, an inverse trend in abundance levels was observed between Proteobacteria and 
343 Cyanobacteria throughout the year. It is unknown what caused this trend and more research

344 needs to be completed to determine if these taxa are impacting each other's growth and

345 abundance levels, or if it is other environmental factors causing this trend.

346 Synechococcus. The genus Synechococcus, decreased in relative abundance during the

347 winter months, or dry season, and increased in abundance during the summer and early fall, or

348 wet season months. Synechococcus spp. are in the Cyanobacteria phylum. Our data correlate

349 with previous observations of increased cyanobacterial blooms in Florida coastal and freshwater

350 ecosystems in the late summer and early fall months. The blooms are caused by warm water

351 conditions paired with increased sunlight levels, and nutrient loading from urban runoff

352 (Flombaum et al., 2013).

353 Thalassiosira. Another taxon seen to fluctuate in abundance with the seasons was the

354 diatom Thalassiosira spp. Previous studies have shown that this genus is a common resident in

355 marine coastal surface waters, and tends shift in abundance on a seasonal cycle, increasing in 356 abundance with spring algal blooms (Heinzelmann et al., 2016). Our results indicate that this

357 organism increased in abundance during dry season months, however it was seen at its highest

358 relative abundance in early spring. While it would be expected that Thalassiosira spp. should

359 increase in abundance during the wet season, it was present in highest abundance in the month of

360 April, the month which marks the start of the wet season.

361 Rhodovibrio. Interestingly, members of the genus Rhodovibrio were seen only in samples

362 in Florida's wet season. Rhodovibrio is a genus commonly seen in oceanic biofilms or microbial

363 mats. There have not been many studies completed on ecosystem roles of Rhodovibrio, although

364 it is known that this organism is classified as a purple non-sulfur bacterium which can secure

365 energy through light by being an photoorganoheterotroph or can secure energy through organic 
366 matter by being a chemoorganoheterotroph (Stal et al., 2017). The Florida wet season spans

367 summer months when typically, more light availability and warmer water temperatures occur.

368 These conditions could have stimulated biofilm formation and proliferation which could explain

369 why members of the Rhodovibrio genus were present in higher abundance during the wet season.

370 Acholeplasma. Fluctuations in abundance were seen in the genus Acholeplasma.

371 Microbes in this genus are in the class Mollicutes and are characterized by lacking a cell wall.

372 Microbes in this genus are known to be commensal organisms in plants, insects, and vertebrates

373 (Kube et al., 2014). It is unlikely that microbes from this taxon are residents of the surface water

374 microbial community, and most likely the presence of this genus in PEI samples is due to size

375 selection when filtering, or because this is the closest classified organism at $97 \%$ sequence

376 similarity in the RDP database.

377 Potential Pathogens

378 PEI represents a point source of pollution introducing harmful pollutants into the

379 surrounding marine environments including the Florida coral reef tract and recreational beaches

380 (Banks et al., 2008 and Stamates et al., 2013). Due to the influence of the inlet waters on the

381 surrounding marine environments, it is important to examine the presence of potentially

382 pathogenic organisms in the inlet waters.

383 The Bacilli class contained two known potentially pathogenic genera Staphylococcus,

384 and Streptococcus. Staphylococcus abundance levels were highest in the months of July and

385 August; however, members of this genus were also present in March and April. Staphylococcus

386 is a genus of gram-positive bacteria commonly found on the nails, skin, and hair of humans (Lian

387 et al, 2012). This taxon can thus be shed directly into coastal waters from bathers. The well-

388 known species in this genus, S. aureus, can also cause illness in humans. S. aureus has a high 
389 resistance to salinity, making it a potential threat to other humans using the contaminated water

390 source for recreational purposes. While this species commonly links to both human symbiosis

391 and illnesses, marine mammals have also been infected (van Elk et al., 2012; Bik et al., 2016).

392 The origin of the strain of $S$. aureus that is contracted by marine mammals was most likely from

393 terrestrial sources introduced into the marine environment via runoff (van Elk et al, 2012).

394 Studies examining the abundance of Staphylococcus over a wet and dry season at a heavily

395 visited coastal area observed increased abundance of $S$. aureus during the wet season (Curiel-

396 Ayala et al., 2012). These data also showed the highest increased abundance of Staphylococcus

397 during Florida's wet season.

398 Streptococcus sp. were present in highest abundance in April. Increased freshwater input

399 and warm water conditions could have been the cause of the increased abundance of these

400 organisms. This presence also coincided during the prime shipping season in Port Everglades,

401 which may have had an impact on abundance levels of Streptococcus spp.

Enterococcus spp. are important fecal indicator bacteria, most often utilized to assess

403 fecal contamination on recreational beaches and coastal areas (Aranda et al., 2015; Heaney et al.,

404 2014; Wade et al., 2003; US Environmental Protection Agency, 1986 and 2004). A recent study

405 examining the number of exceedances of enterococci on recreational beaches in Miami-Dade

406 County, FL from 2000-2010 (Aranda et al., 2015) showed that beaches were only in exceedance

407 of the allowable levels of enterococci $3 \%$ of the time. This study examined data generated by the

408 Florida Healthy Beaches Program, which samples weekly. No patterns in regard to rainfall or

409 storms were seen in correlation with enterococci exceedances, although this may be due to the

410 sampling frequency and high decay rate of enterococci in marine waters (Aranda et al., 2015). In

411 contrast to this, a study completed by Curiel-Ayala and colleagues in Mexico (2012), showed 
412 increased Enterococcus levels during the rainy season, and the highest concentrations of the

413 genus corresponding to highest tourist presence. The highest levels of enterococci seen in the

414 Miami-Dade study were in March and October, which could be due to high tidal levels in

415 October, and possible tourism influences in the month of March overlapping with spring break

416 (Aranda et al., 2015). It was expected that presence of Enterococcus spp. would be in highest

417 abundance in PEI during March-April when shipping season and tourist season start.

418 Interestingly, Enterococcus spp. were not observed in any of the samples taken in PEI. This was

419 also seen in the previous study examining presence of pathogens in PEI (Campbell et al., 2015).

420 It is possible that Enterococcus spp. are not prevalent inhabitants in PEI. More intensive studies

421 would need to be completed to determine if there is the presence of Enterococcus spp. in PEI.

422 It was interesting that the causative agent of the white pox disease for coral Acropora

423 palmata, human fecal bacteria $S$. marcescens was not observed in the top 100 OTUs in the

424 Enterobacteriales class. A recent high throughput molecular study of coral white band disease

425 identified only 5 orders with large numbers of disease-associated OTUs: Flavobacteriales,

426 Alteromonadales, Oceanospirillales, Campylobacterale and Rhodobacterales (Gignoux-

427 Wolfsohn and Vollmer, 2015). Also of note, is the absence of Vibrionales pathogens in our

428 dataset. The previous analysis of PEI microbiomes by Campbell et al (2015) showed a low

429 abundance of Vibrionales.

430 While it is intriguing that potentially pathogenic genera were detected in PEI, it is not

431 possible to conclude that these organisms are virulent without culturing, in depth metagenomic

432 sequencing, or oligotyping analyses (Eren et al, 2013). A general pitfall of 16S amplicon

433 sequencing is the lack of taxonomic resolution down to the species and strain level. Without this

434 level of classification pathogenicity cannot be confirmed. A previous $16 \mathrm{~S}$ amplicon and shotgun 
435 sequencing study completed on the microbiomes present in the subway system in Boston,

436 showed that there were very few antibiotic resistant genes and virulence factors found in the

437 samples. They also found that there were very few sequences that were identified as

438 opportunistic pathogens or potentially pathogenic organisms (Hsu et al. 2016). This suggests that

439 most likely the microbes identified in this study did not contain virulence factors and are non-

440 pathogenic commensals living in the inlet. However, future research utilizing deeper sequencing

441 and culture-based methods should be completed to further examine presence of pathogens in

442 PEI.

443 Significance and Conclusions

444 This study has provided one of the first in-depth profiles of the bacterioplankton

445 community in metropolitan S. Florida inlet waters. The current dataset complements and expands

446 upon a previous a pilot HTP study characterizing the bacterioplankton community of Port

447 Everglades inlet and surrounding coastal waters. Specific marine habitats, such as coral reefs or

448 mangroves, have well defined optimal conditions for thriving and can be sensitive to small

449 perturbations (Precht and Miller 2007; Hoegh-Guldberg et al., 2007). The data from this study

450 will be helpful to local environmental managers, such as the Southeast Florida Coral Reef

451 Initiative (SEFCRI, http://www.dep.state.fl.us/coastal/programs/coral/sefcri. htm), which aims to

452 protect and monitor S. Florida reef habitats. The timeframe of this study appeared poignant,

453 showing that anomalous weather patterns (dry August) can affect community composition. This

454 study also preceded a protracted 2014-2016 El Niño event outbreak of coral disease on the

455 Florida reef tract in 2014 and the planned expansion and deepening of PEI in the upcoming

456 years. Understanding the microbial composition in the inlet prior to these perturbations will 
457 458 459 460 461

462

463

464

465

466

467

468

469

470

471

472

473

474

475

476

477

478

479

480

481

482

483

484

485

486

487

488

489

490

491

492

493

494

495

496

497 contribute to better management and mitigation of the environment and may help to protect the adjacent coral reef where the inlet outflows.

\section{References}

Aranda D, Lopez JV, Solo-Gabriele HM, Fleisher JM. 2015. Using probabilities of enterococci exceedance and logistic regression to evaluate long term weekly beach monitoring data. Journal of Water and Health. 14(1):81-89. DOI:10.2166/wh.2015.030.

Arrigo KR. 2004. Marine microorganisms and global nutrient cycles. Nature. 437: 349-355. DOI:10.1038/nature04159

Azam F, Fenchel T, Field JG, Gray JS, Meyer-Reil L, Thingstad F. 1983. The ecological role of water-column microbes in the sea. Marine Ecology Progress Series. 10:257-263. DOI:0171$8630 / 83 / 0010 / 0257 / \$ 02.00$

Banks KE, Riegl BM, Richards VP, Walker BE, Helmle KP, Jordan LKB, Phipps J, Shivji M, Spieler RE, and Dodge RE. 2008. Chapter 5: The reef tract of continental Southeast Florida (Miami-Dade, Broward, and Palm Beach Counties, USA). In: Coral Reefs of the USA. Dordrecht: Springer Verlag,175-220.

Bik EM, Costello EK, Switzer AD, Callahan BJ, Holmes SP, Wells RS, Carlin KP, Jensen ED, Venn-Watson S, Relman DA. 2016. Marine mammals harbor unique microbiotas shaped by and yet distinct from the sea. Nature Communications. 7. DOI:10.1038/ncomms10516

Bowman JP, Nowak B. 2004. Salmonid gill bacteria and their relationship to amoebic gill disease. Journal of Fish Diseases. 27(8): 483-492.

Callahan BJ, McMurdie PJ, Rosen MJ, Han AW, Johnson AJ, Holmes SP. 2016. DADA2: Highresolution sample inference from Illumina amplicon data. Nature Methods. 13(7):581-583.

Callahan BJ, McMurdie PJ, Rosen MJ, Han AW, Johnson AJA, Holmes SP. DADA2: High resolution sample inference from Illumina amplicon data. Nature methods. 2016;13(7):581-583. doi:10.1038/nmeth.3869.

Campbell AM, Fleisher J, Sinigalliano C, White JR, Lopez JV. 2015. Dynamics of marine bacterial community diversity of the coastal waters of the reefs, inlets, and wastewater outfalls of southeast Florida. MicrobiologyOpen. 1-19. DOI: 10.1002/mbo3.245

Canfield DE, Glazer AN, Falkowski PG. 2010. The evolution and future of Earth's nitrogen cycle. Science. 330(6001): 192-196. DOI:10.1126/science.1186120 
498 a Caporaso JG, Kuczynski J, Stombaugh J, Bittinger K, Bushman FD, Costello EK, Fierer N, 499 Pena AG, Goodrich JK, Gordon JI, Huttley, GA, Kelley ST, Knights D, Koenig JE, Ley RE, 500 Lozupone CA, McDonald D, Muegge BD, Pirrung M, Reeder J, Sevinsky JR, Turnbaugh PJ, 501 Walters WA, Widmann J, Yatsunenko T, Zaneveld J, Knight R, 2010. QIIME allows analysis of 502 high-throughput community sequence data. Nature Methods. 7(5): 335-336.

503 DOI:10.1038/nmeth.f.303

504

505

506

507

508

509 Carrie Futch, J, Griffin, DW, Banks, K, Lipp, EK. 2011. Evaluation of sewage source and fate on

510

511

512

513

514

515

516

517

518

519

520

521

522

523

524

525

526

527

528

529

530

531

532

533

534

535

536

537

538

539 southeast Florida coastal reefs. Marine Pollution Bulletin. 62(11): 2308-2316.

${ }^{b}$ Caporaso JG, Bittlinger K, Bushman FD, DeSantis TZ, Andersen GL, Knight R. 2010. PyNAST: a flexible tool for aligning sequences to a template alignment. Bioinformatics. 26(2): 266-267. DOI: 10.1093/bioinformatics/btp636

https://doi.org/10.1016/j.marpolbul.2011.08.046

Carsey TP, Stamates JS, Bishop JR, Brown CJ, Casanova HL, Featherstone CM, Gidley ML, Kosenko M, Kotkowski RM, Sinigalliano CD, Visser LA, Zhang, JZ 2013: Broward County coastal ocean: Water quality cruises, 2010-2012. NOAA Technical Report (in preparation).

Cho J-C, Giovannoni SJ. 2003. Croceibacter atlanticus gen. nov., sp. nov., a novel marine bacterium in the family Flavobacteriaceae. Systematic and Applied Microbiology. 26(1): 76-83. https://doi.org/10.1078/072320203322337344

Curiel-Ayala F, Quinones-Ramirez EI, Pless RC, Gonzalez-Jasso, E. 2012. Comparative studies on Enterococcus, Clostridium perfringens, and Staphylococcus aureus as quality indicators in tropical seawater at a Pacific Mexican beach resort. Marine Pollution Bulletin, 64(10): 21932198. DOI:10.1016/j.marpolbul.2012.07.052

DeSantis TZ, Hugenholtz P, Larsen N, Rojas M, Brodie EL, Keller K, Huber T, Dalevi D, Hu P, Andersen GL. 2006. Greengenes, a chimera-checked 16S rRNA gene database and workbench compatible with ARB. Applied and Environmental Microbiology. 72(7):5069-5072. DOI:10.1128/AEM.03006-05

Duce RA, LaRoche J, Altieri K, Arrigo KR, Baker AR, Capone DG, Cornell S, Dentener F, Galloway J, Ganeshram RS, Geider RJ, Jickells T, Kuypers MM, Langlois R, Liss PS, Liu SM, Middelburg JJ, Moore CM, Nickovic S, Oschlies A, Pedersen T, Prospero J, Schlitzer R, Seitzinger S, Sorensen LL, Uematsu M, Ulloa O, Voss M, Ward B, Zamora L. 2008. Impacts of Atmospheric Anthropogenic Nitrogen on the Open Ocean. Science. 320(5878): 893-897. DOI:10.1126/science.1150369

Edgar RC. 2010. Search and clustering orders of magnitude faster than BLAST. Bioinformatics. 540 
541 Elifantz H, Horn G, Ayon M, Cohen Y, Minz D. 2013. Rhodobacteraceae are the key members 542 of the microbial community of the initial biofilm formed in Eastern Mediterranean coastal 543 seawater. FEMS Microbiology Ecology. 85: 348-357. DOI:10.1111/1574-6941.12122

544 Eren AM, Maignien L, Sul WJ, Murphy LG, Grim SL, Morrison HG, Sogin ML. 2013.

545 Oligotyping: differentiating between closely related microbial taxa using 16S rRNA gene data.

546 Methods in Ecology and Evolution. 4(12):1111-1119.

547 Finkl CW, Charlier RH. 2003. Sustainability of subtropical coastal zones in southeastern Florida:

548 Challenges for urbanized coastal environments threatened by development, pollution, water

549 supply, and storm hazards. Journal of Coastal Research. 19(4): 934-943.

550

551

552

553

554

555

556

557

558

559

560

561

562

563

564

565

566

567

568

569

570

571

572

573

574

575

576

577

578

579

580

581

582

583

Flombaum P, Gallegos JL, Gordillo RA, Rincon J, Zabala LL, Jioa N, Karl DM, Li WKW, Lomas MW, Veneziano D, Vera CA, Vrugt JA, Martiny AC. 2013. Present and future global distributions on marine Cyanobacteria Prochlorococcus and Synechococcus. PNAS. 110(24): 9824-9829. www.pnas.org/cgi/doi/10.1073/pnas.1307701110

Futch JC, Griffin DW, Banks K, Lipp EK. 2011. Evaluation of sewage source and fate on Southeast Florida coastal reefs. Marine Pollution Bulletin. 62(11):2308-2316. DOI:10.1016/j.marpolbul.2011.08.046

Gao S. 2015. Managing short-lived climate forcers in curbing climate change: An atmospheric chemistry synopsis. Journal of Environmental Studies and Sciences. 5: 130 - 137. DOI:10.1007/s13412-014-0207-7

Gifford SM, Sharma S, Moran MA. 2014. Linking activity and function to ecosystem dynamics in a coastal bacterioplankton community. Frontiers in Microbiology. 5:1-12.

DOI:10.3389/fmicb.2014.00185

Gignoux-Wolfsohn SA, Vollmer SV. 2015. Identification of candidate coral pathogens on white band disease-infected staghorn coral. PLOS ONE. 10(11): 0142760.

https://doi.org/10.1371/journal.pone. 0142760

Gomez-Pereira PR, Fuchs BM, Alonso C, Oliver MJ, van Beusekom JE, Amann R 2010. Distinct flavobacterial communities in contrasting water masses of the North Atlantic. ISME. 4(4):472-487. DOI:10.1111/j.1462-2920.2011.02601

Heaney CD, Exum NG, Dufour AP, Brenner KP, Haugland RA, Chem E, Schwab KJ, Love DC, Serre ML, Noble R, Wade T. 2014. Water quality, weather and environmental factors associated with fecal indicator organiam density in beach sand at two recreational marine beaches. Science of The Total Environment. 497-498:440-447. DOI:10.1016/j.scitotenv.2014.07.113

Heinzelmann SM, Bale NJ, Villanueva L, Sinke-Schoen D, Johanna C, Phillippart M, Smede Sinninghe Damste J, Schouten S, Teunis Jan van der Meer M. 2016. Seasonal changes in the $\mathrm{D} / \mathrm{H}$ ratio of fatty acids of pelagic microorganisms in the coastal North Sea. Biogeosciences. 13 5527-5539. doi:10.5194/bg-13-5527-2016 
584

585

586

587

588

589

590

591

592

593

594

595

596

597

598

599

600

601

602

603

604

605

606

607

608

609

610

611

612

613

614

615

616

617

618

619

620

621

622

623

624

625

626

627

628

629

Hoegh-Guldberg O, Mumby PJ, Hooten AJ, Steneck RS, Greenfield P, Gomez E, Harvell CD, Sale PF, Edwards AJ, Caldeira K, Knowlton N, Eakin CM, Iglesias-Prieto R, Muthiga N, Bradbury RH, Dubi A, Hatziolos ME. 2007. Coral reefs under rapid climate change and ocean acidification. Science. 318(5857):1737-1742. DOI:10.1126/science.1152509

Hsu T, Joice R, Vallarino J, Abu-Ali G, Hartmann EM, Shafquat A, DuLong C, Baranowski C, Gevers D, Green JL, Morgan XC, Spengler JD, Huttenhower C. 2016. Urban transit system microbial communities differ by surface type and interaction with humans and the environment. mSystems. 1(3):1-18. DOI:10.1128/mSystems.00018-16

Illumina. 2013. 16S Metagenomic Sequencing Library Preparation.

https://support.illumina.com/content/dam/illumina-

support/documents/documentation/chemistry_documentation/16s/16s-metagenomic-library-prepguide-15044223-b.pdf

Kube M, Siewert C, Migdoll AM, Duduk B, Holz S, Rabus R, Seemuller E, Mitrovic J, Muller I, Buttner C, Reinhardt R. 2014. Analysis of the complete genomes of Acholeplasma brassicae, A palmae and A laidlawii and their comparison to the obligate parasites from 'Candidatus Phytoplasma' Journal of Molecular Microbiology and Biotechnology. 24(1): 19-36. https://doi.org/10.1159/000354322

Lapointe, BE, Herren, LW, Debortoli, DD, Vogel, MA. 2015. Evidence of sewage-driven eutrophication and harmful algal blooms in Florida's Indian River Lagoon. Harmful Algae. 43: 82-102. https://doi.org/10.1016/j.hal.2015.01.004

Lewis, C. L., Neely, K. L., Richardson, L. L., \& Rodriguez-Lanetty, M. (2017). Temporal dynamics of black band disease affecting pillar coral (Dendrogyra cylindrus) following two consecutive hyperthermal events on the Florida Reef Tract. Coral Reefs, 36(2), 427-431.

Lian PY, Maseko T, Rhee M, Ng K. 2012. The antimicrobial effects of cranberry against Staphylococcus aureus. Food Science and Technology International, 18(2): 179-186. DOI:10.1177/1082013211415159

Li W, Godzik A. 2006. Cd-hit: a fast program for clustering and comparing large sets of protein or nucleotide sequencies. Bioinformatics. 22(13):1658-1659.

DOI:10.1093/bioinformatics/bt1158.

Mallin, MA, Williams, KE, Cartier Esham, E, Lowe RP. 2000. Effect of human development on bacteriological water quality in coastal watersheds. Ecological Applications. 10(4): 1047-1056.

Mandal S, Van Treuren W, White RA, Eggesbo M, Knight R, Peddada SD. 2015. Analysis of composition of microbiomes: a novel method for studying microbial composition. Microb Ecol Health Dis. doi: 10.3402/mehd.v26.27663

Marcus, N. 2004. An overview of the impacts of eutrophication and chemical pollutants on 
630 copepods of the coastal zone. Zoological Studies. 43(2): 211-217.

631

632

633

634

635

636

637

638

639

640

641

642

643

644

645

646

647

648

649

650

651

652

653

654

655

656

657

658

659

660

661

662

663

664

665

666

667

668

669

670

671

672

673

674
Masella AP, Bartram AK, Truszkowski JM, Brown DG, Neufeld JD. 2012. PANDAseq: pairedend assembler for illumina sequences. Biomed Central Bioinformatics. 13:31.

DOI:10.1186/1471-2105-13-31

McDonald D, Price MN, Goodrich J, Nawrocki EP, DeSantis TZ, Probst A, Andersen GL, Knight R, Hugenholtz P. 2012. An improved Greengenes taxonomy with explicit ranks for ecological and evolutionary analyses of bacteria and archaea. ISME Journal. 6(3): 610-618. DOI:10.1038/ismej.2011.139

McMurdie PJ, Holmes S. 2013. Phyloseq: An R package for reproducible interactive analysis and graphics of microbiome census data. PLoS ONE, 8(4):e61217

Miller MW, Karazsia J, Groves CE, Griffin S, Moore T, Wilber P, Gregg K. 2016. Detecting sedimentation impacts to coral reefs resulting from dredging the Port of Miami, Florida USA. PeerJ. 4(e2711):DOI:10.7717/peerj.2711

NOAA National Centers for Environmental information (http://www.ncdc.noaa.gov/cag/)

NOS (National Ocean Service, National Oceanic and Atmospheric Administration), 2011. Coast Pilot 4. Atlantic Coast Cape Henry to Key West, $43^{\text {rd }}$ ed. Chapter 10, St. John's River to Miami, 328-332.

Paerl HW, Dyble J, Moisander PH, Noble RT, Piehler MF, Pinckney JL, Steppe TF, Twomey L, Valdes LM. 2003. Microbial indicators of aquatic ecosystem change: current applications to eutrophication studies. FEMS Microbiology Ecology. 46(3):233-246.

https://doi.org/10.1016/S0168-6496(03)00200-9

Port Everglades Fiscal Year 2016 Commerce Report. Available at https://res.cloudinary.com/simpleview/image/upload/v1/clients/porteverglades/PEG779_Comme rce_Report_FY2016_ddd1ccd4-f343-4aae-9382-11b5e1af0ebd.pdf (accessed 02 July 2017).

Precht WF, Miller, SL. 2007. Ecological shifts along the Florida Reef Tract: The Past is a key to the future. In Geological Approaches to Coral Reef Ecology. R.B. Aronson. Chapter 9:237-312. United States:Springer NY.

QIIME2. https://qiime2.org.

Rappe MS, Connan SA, Vergin KL, Giovannoni SJ. 2002. Cultivation of the ubiquitous SAR11 marine bacterioplankton clade. Nature. 418: 630-633. DOI:10.1038/nature00917

Rohwer F, Youle M, Vosten D, 2010. Coral Reefs in the Microbial Seas (Vol. 1). United States: Plaid Press. 
675 Somboonna N, Wilantho A, Assawamakin A, Monanunsap S, Sangsrakru D, Tangphatsornruang

676 S, Tongsima S. 2014. Structural and functional diversity of free-living microorganisms in reef

677 surfacem Kra island, Thailand. BMC Genomics 15(607). https://doi.org/10.1186/1471-2164-15-

678607

679

680 Stal LJ, Bolhuis H, Cretoiu MS. 2017. Phototrophic microbial mats. Modern Topics in

681 Phototrophic Prokaryotes. 295-318.

682

683

Staley C, Kaiser T, Gidley ML, Enochs IC, Jones PR, Goodwin KD, Sinigalliano CD, Sadowsky

684

685

686

687

688

689

690 MJ, Chun CL. 2017. A next-generation sequencing approach to characterize the impacts of landbased sources of pollution on the microbiota of southeast Florida coral reefs. Applied and Environmental Microbiology 83; 1-27. DOI:10.1128/AEM.03378-16

Stamates SJ, Bishop JR, Carsey TP, Featherstone CM, Gidley ML, Kelble CR, Kotkowski, RM, Roddy RJ. 2013. Port Everglades Flow Measurement System. NOAA Technical Report, OARAOML-42.1-22.

691

692

693

694

695

696

697

698

699

700

701

702

703

704

705

706

707

Stauble DK. 1993. An overview of southeast Florida inlet morphodynamics. Journal of Coastal Research: 1-27. http://www.jstor.org/stable/25735671

Sunagawa S, Coelho LP, Chaffron S, Kultima JR, Labadie K, Salazar G, Djahanschiri B, Zeller G, Mende DR, Alberti A, Cornejo-Castillo FM, Costea PI, Cruaud C, d'Ovidio F, Engelen S, Ferrera I, Gasol JM, Guidi L, Hildebrand F, Kokozka F, Lepoivre C, Lima-Mendez G, Poulain J, Poulos BT, Royo-Llonch M, Sarmento H, Vieira-Silva S, Dimier C, Picheral M, Searson S, Kandels-Lewis S, Tara Oceans coordinators, Bowler C, de Vargas C, Gorsky G, Grimsley N, Hingamp P, Ludicone D, Jaillon O, Not F, Ogata H, Pesant S, Speich S, Stemmann L, Sullivan MB, Weissenbach J, Wincker P, Karsenti E, Raes J, Acinas SG, Bork P. 2015. Structure and function of the global ocean microbiome. Nature. 348(6237).

Sutherland, KP, Shaban, S, Joyner JL, Porter, JW, Lipp EK. 2011. Human pathogen shown to cause disease in the threatened elkhorn coral Acropora palmate. 2011. PloSONE. https://doi.org/10.1371/journal.pone.0023468

709

710

Symonds EM, Sinigalliano C, Gidley M, Ahmed W, McQuaig-Ulrich SM, Breitbart M. 2016. Faecal pollution along the southeastern coast of Florida and insight into the use of pepper mild mottle virus as an indicator. Journal of Applied Microbiology. 121(5): 1469-1481.

711 DOI:10.1111/jam.13252

712

713

714

715

716

717

The Official Site of the Broward County Port Everglades Department. Available at http://www.porteverglades.net (accessed 10 July 2017).

719

Thompson LR, Sanders JG, McDonald D, Amir A, Ladau J, Locey KJ, Prill RJ, Tripathi A, Gibbons SM, Ackermann G, Navas-Molina JA, Janssen S, Kopylova E, Vazquez_Baeza Y, Gonzalez A, Morton JT, Mirarab S, Xu ZZ, Jiang L, Haroon MF, Kanbar J, Zhu Q, Song SJ, Kosciolek T, Bokulich NA, Lefler J, Brislawn CJ, Humphrey G, Owens SM, Hampton-Marcell

720 J, Berg-Lyons D, McKenzie V, Fierer N, Fuhrman JA, Clauset A, Stevens RL, Shade A, Pollard 
721

722

723

724

725

726

727

728

729

730

731

732

733

734

735

736

737

738

739

740

741

742

743

744

745

746

747

748

749

750

751

752

753

754

755

756

757

758

759

760

761

762

763

KS, Goodwin KD, Jansson JK, Gilbert JA, Knight R, The Earth Microbiome Consortium. A communals catalogue reveals Earth's multiscale microbial diversity. Nature. 551(7681).

Tully B, Sachdeva R, Heidlberg KB, Heidlberg JF. 2014. Comparative genomics of planktonic Flavobacteriaceae from the Gulf of Maine using metagenomics data. Microbiome. 2(34). DOI:10.1186/2049-2618-2-34

US Environmental Protection Agency. (1986). Ambient water quality criteria for bacteria 1986. EPA 440/5-84-002. Office of Water Regulations and Standards, US Envrionmental Protection Agency, Washington, DC.

US Environmental Protection Agency. 2004. Implementation guidance for ambient water quality criteria for bacteria. EPA-823-B-04-002. US Environmental Protection Agency, Washington, DC.

United States Census Bureau. Available at

https://www.census.gov/quickfacts/fact/table/browardcountyflorida,FL/PST045216. (accessed 2 July 2017).

US Army Corps of Engineers. Port Everglades Fact Sheet. Available at:

http://www.saj.usace.army.mil/Portals/44/Port\%20Everglades\%20FS-

FAQ\%2024Mar17\%20final.pdf (accessed 02 July 2017).

van Elk CE, Boelens HA, van Belkum A, Foster G, Kuiken T. 2012. Indications for both hostspecific and introduced genotypes of Staphylococcus aureus in marine mammals. Veterinary Microbiology. 156(3-4): 343-346. DOI:10.1016/j.vetmic.2011.10.034.

Wade TJ, Pai N, Eisenberg JN, Colford JM. 2003. Do US Environmental Protection Agency water quality guidelines for recreational water prevent gastrointestinal illness? A systematic review and meta-analysis. Environmental Health Perspective, 111(8): 1102-1109.

Walker BK, Riegl B, Dodge RE. 2008. Mapping coral reef habitats in southeast Florida using a combined technique approach. Journal of Coastal Research. 24(5):1138-1150.

https://doi.org/10.2112/06-0809.1

Wallace JC, Youngblood JE, Port JA, Cullen AC, Smith MN, Workman T, et al. 2018.

Variability in metagenomic samples from the Puget Sound: Relationship to temporal and anthropogenic impacts. PLoS ONE 13(2): e0192412.

https://doi.org/10.1371/journal.pone.0192412

Whittaker RH. 1972. Evolution and measurement of species diversity. Taxon. 21(2/3): 213-251. DOI: $10.2307 / 1218190$

Wickham H. 2011. The split-apply-combine strategy for data analysis. Journal of Statistical Software. 40(1):1-29. DOI:10.18637/jss.v040.i01 
Figure 1

Alpha diversity measurements of PEI microbiome

(A) Comparison of species evenness in PEl between seasons. Pielou's Evenness values were used to calculate species evenness. Significant differences were observed between seasons of PEI for species evenness, with the dry season having lower species evenness $(p=0.020)$. (B) The comparison of species richness in PEl between seasons. Faith's Phylogenetic Diversity values were used to calculate species richness. Significant differences were observed between seasons of PEI for species richness, with the wet season having higher species richness values $(p=0.025)$.

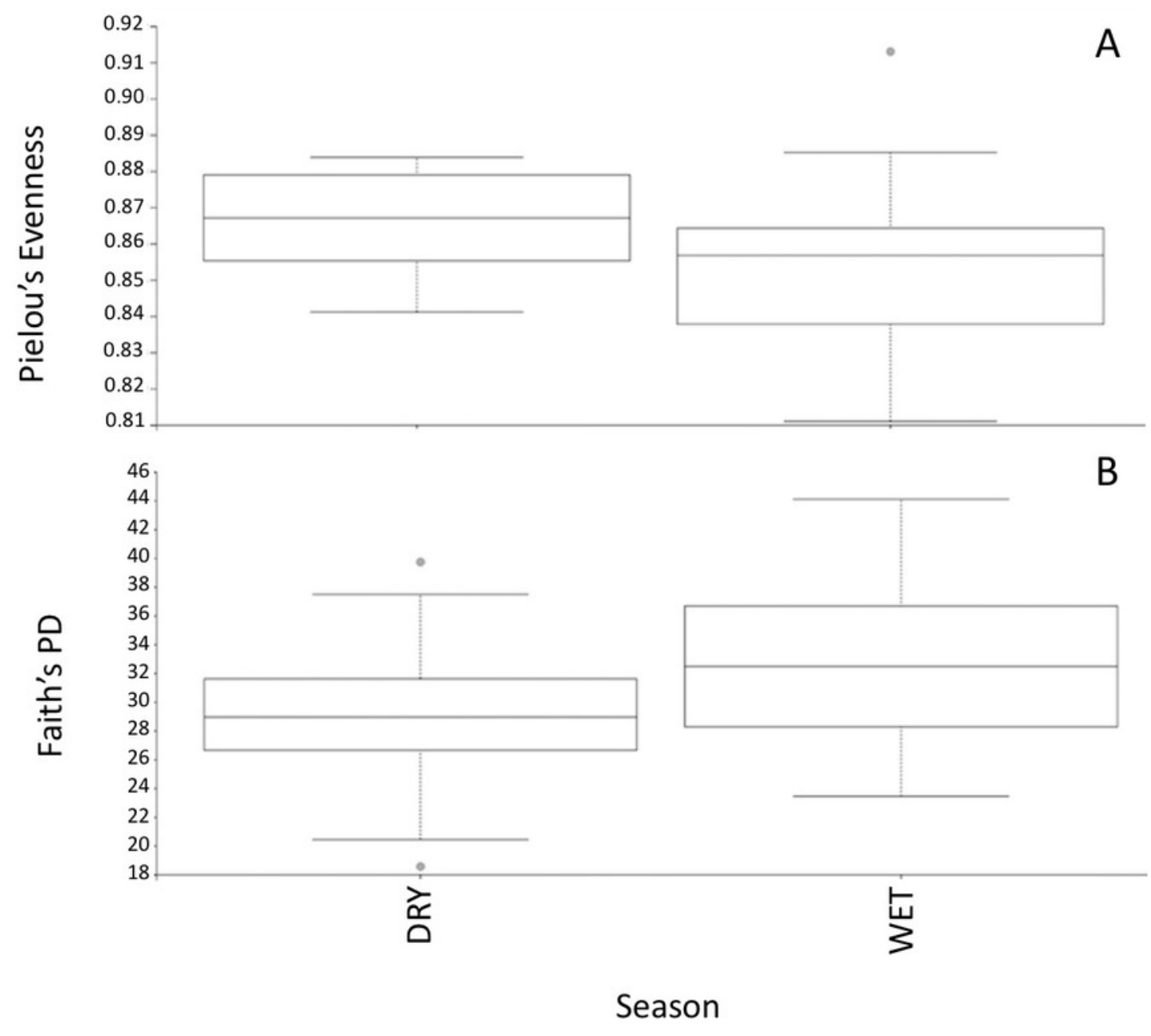


Figure 2

Beta diversity measurements of PEI microbiome

Principle Coordinate Analysis of PEI water samples using Bray-Curtis distance. Clustering of points indicates sample similarity. Significant differences in beta diversity were observed between the wet and the dry season $(p=0.001)$.

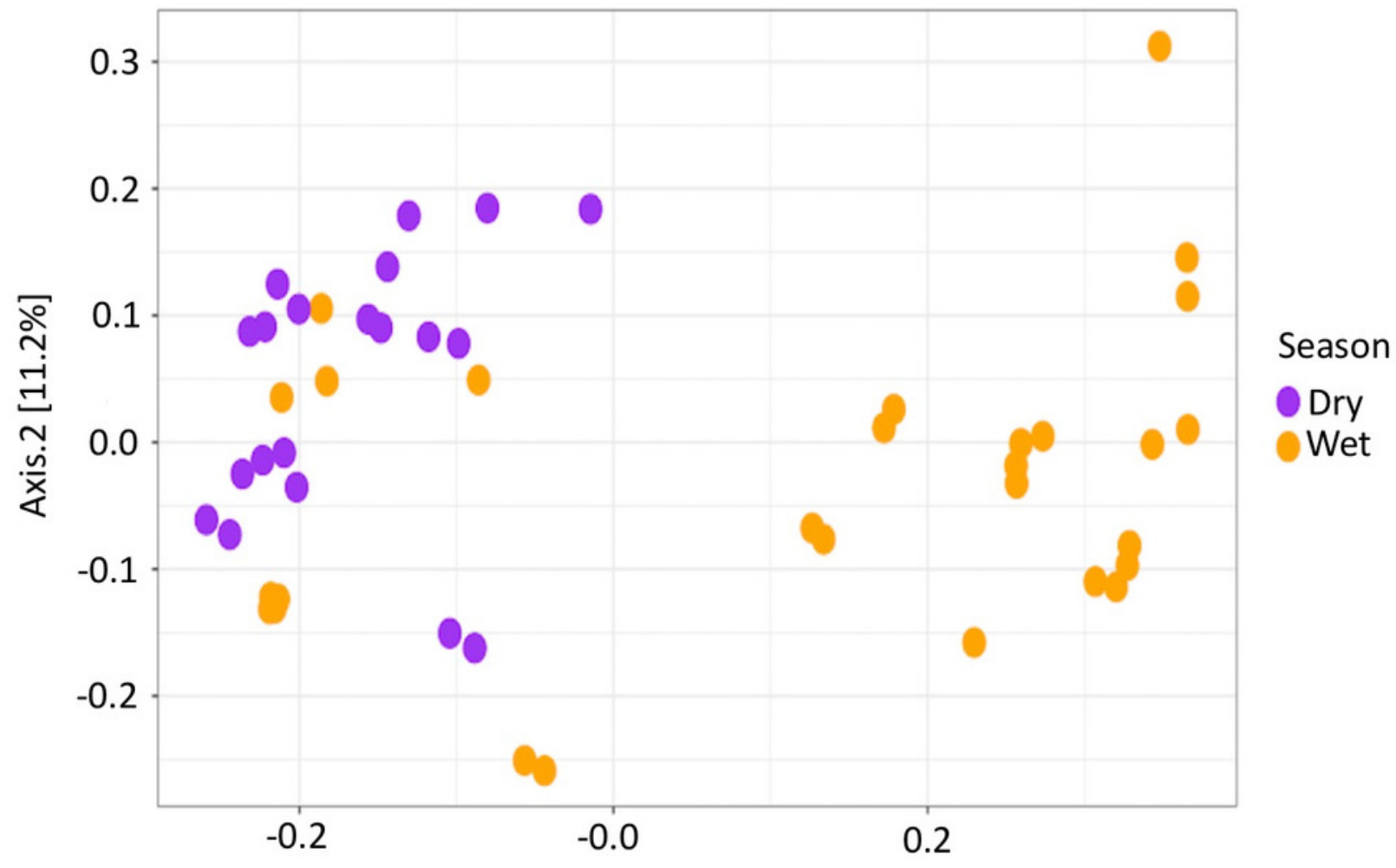

Axis.1 [40.4\%] 


\section{Figure 3}

Comparison of relative abundance values of genus-level taxa between seasons.

Stacked bar chart displaying seasonal fluctuations of relative abundance levels at genus-level classification. Synechococcus was the only taxon to have significantly different abundance levels between the wet and the dry season.

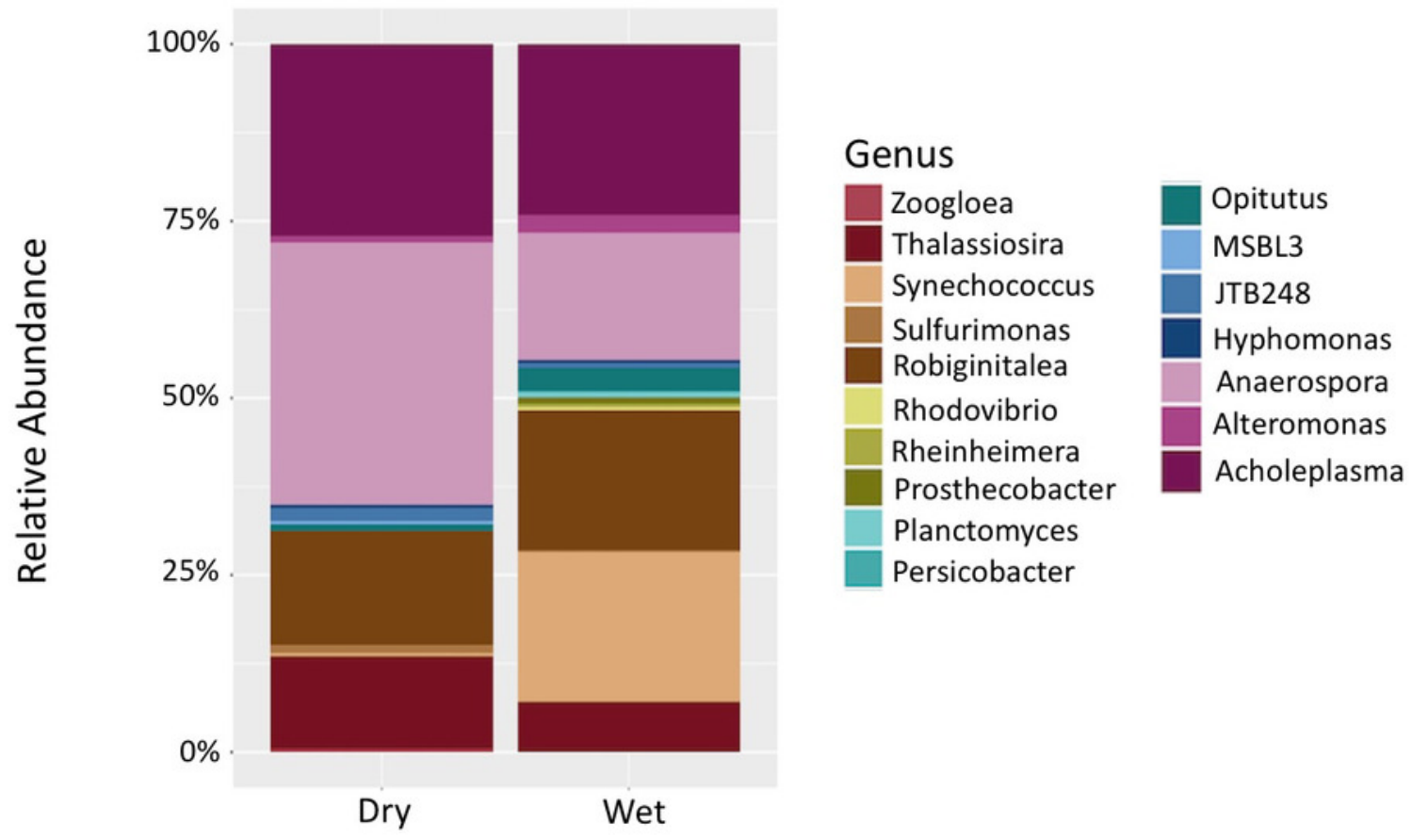




\section{Figure 4}

Average rainfall and temperature values for PEI from July 2013 to June 2014.

(A) The average rainfall values for $\mathrm{PEI}$ and surrounding areas. The red line indicates the average rainfall levels for PEI during the study. The black line indicates the historical average of rainfall levels for PEI and surrounding areas. The black line is comprised data collected from 1981-2010. (B) The average temperature values for PEI. The red line indicates the average temperature values during the current study. The black line indicates the historical average of temperature values for PEI. The black line is comprised of data collected from 1981-2010. The historical averages were obtained from: https://www.ncdc.noaa.gov/cdoweb/datatools/normals
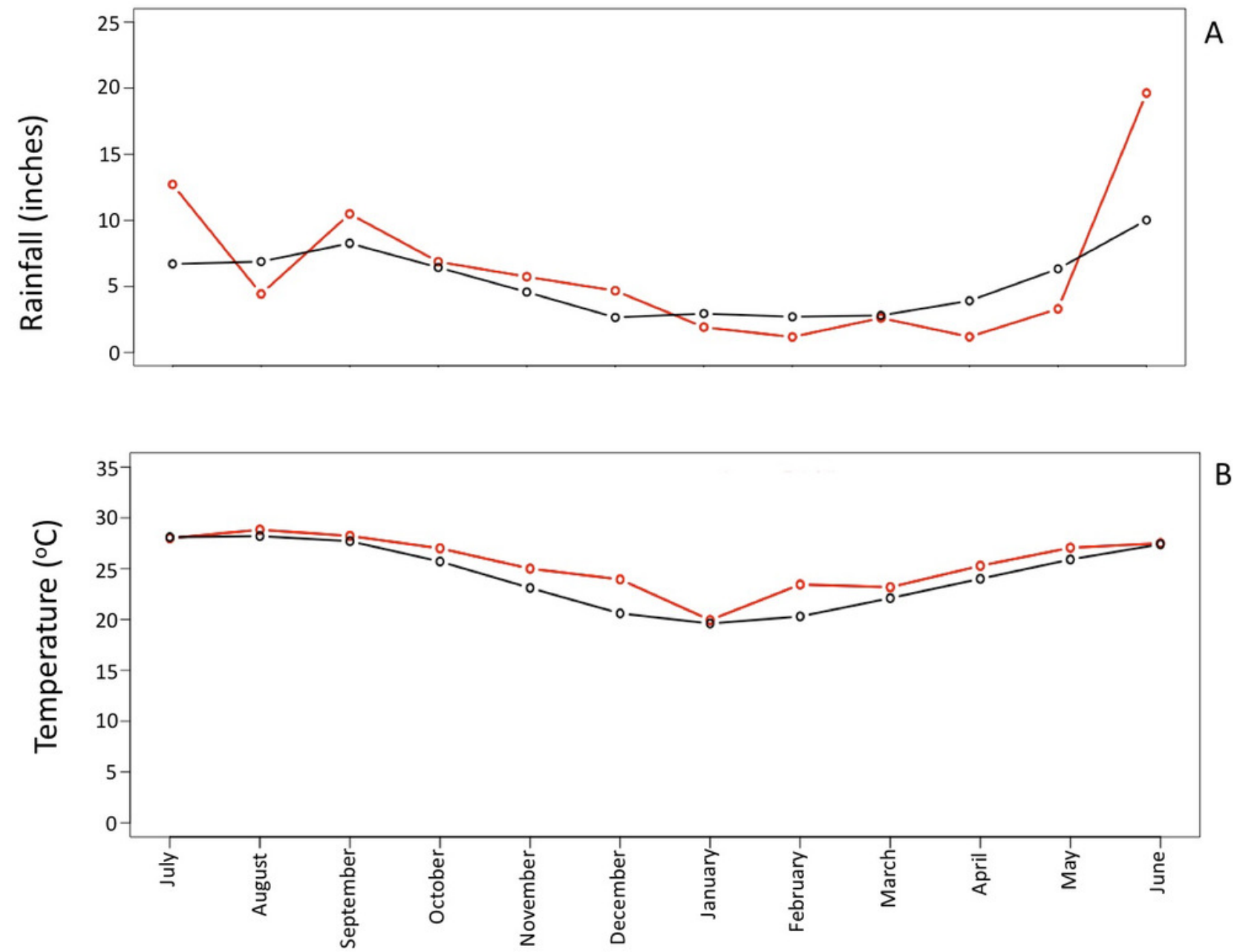
Figure 5

Comparison of relative abundance levels of potentially pathogenic genera in PEI.

(A) Stacked bar chart displaying the prevalence of Staphylococcus spp. between wet and dry season. Each box comprising the bars in the plots is a different OTU. (B) Stacked bar chart displaying the prevalence of Streptococcus spp.between wet and dry season. Staphylococcus spp. were present in much higher relative abundance levels than Streptococcus spp. as displayed by the different $y$-axis scales.

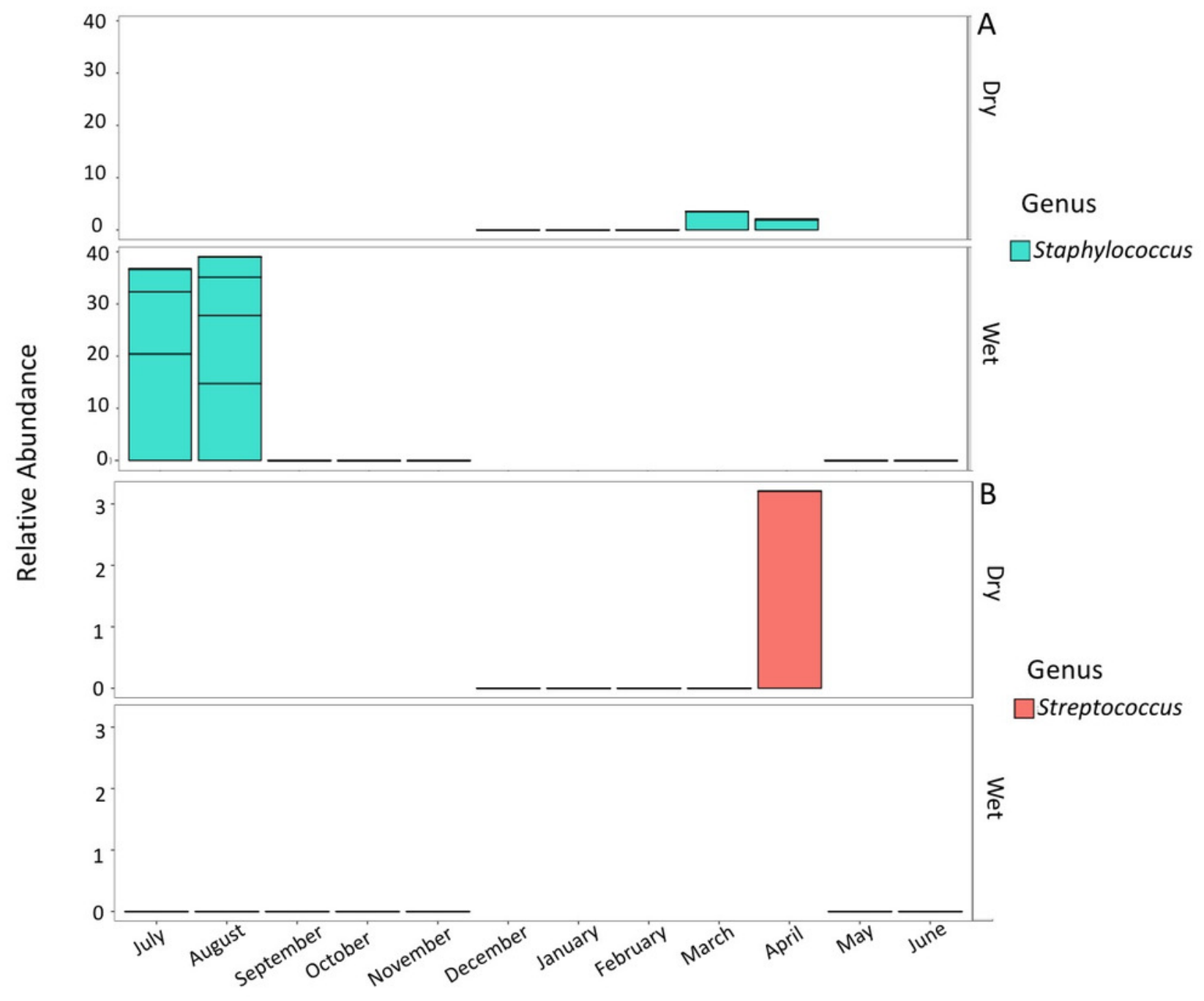




\section{Table $\mathbf{1}$ (on next page)}

ANCOM test results for differential abundance of Synechococcus spp.

The ANCOM results for Synechococcus spp. that differed significantly in abundance levels between seasons. High W values indicate significant differences in abundance levels between seasons. The higher the $\mathrm{W}$ value the more significant the differences in abundance levels between seasons. 


\begin{tabular}{|c|c|c|c|c|c|c|c|c|c|c|c|c|}
\hline Percentile & $\mathbf{0}$ & 25 & 50 & 75 & 100 & $\mathbf{0}$ & 25 & 50 & 75 & 100 & & \\
\hline OTU & Dry & Dry & Dry & Dry & Dry & Wet & Wet & Wet & Wet & Wet & Reject null hypothesis & $\mathbf{w}$ \\
\hline Unidentified Synechococcus sp. 1 & 1 & 1 & 42.5 & 60.5 & 159 & 31 & 86.25 & 120 & 159.75 & 313 & TRUE** & 14 \\
\hline Unidentified Synechococcus sp. 3 & 1 & 1 & 1 & 1 & 11 & 1 & 1 & 1 & 1 & 21 & TRUE** & 13 \\
\hline Unidentified Synechococcus sp. 7 & 86 & 160.25 & 378 & 539.5 & 2172 & 231 & 822 & 1725 & 2411.25 & 4189 & TRUE** & 11 \\
\hline Unidentified Synechococcus sp. 8 & 1 & 1 & 1 & 1 & 34 & 1 & 1 & 1 & 1 & 57 & TRUE** & 13 \\
\hline Unidentified Synechococcus sp. 9 & 1 & 1 & 1 & 1 & 1 & 1 & 1 & 1 & 1 & 25 & TRUE** & 13 \\
\hline Unidentified Synechococcus sp. 15 & 1 & 1 & 1 & 1 & 1 & 1 & 1 & 51.5 & 123.25 & 237 & TRUE** & 18 \\
\hline Unidentified Synechococcus sp. 18 & 1 & 1 & 1 & 1 & 1 & 1 & 1 & 12.5 & 51 & 98 & TRUE** & 11 \\
\hline Unidentified Synechococcus sp. 20 & 1 & 1 & 1 & 1 & 1 & 1 & 1 & 32.5 & 64.25 & 213 & TRUE** & 15 \\
\hline Unidentified Synechococcus sp. 21 & 97 & 164.25 & 202.5 & 292.75 & 539 & 44 & 129.25 & 179 & 301.75 & 752 & TRUE** & 13 \\
\hline Unidentified Synechococcus sp. 24 & 1 & 1 & 1 & 1 & 1 & 1 & 1 & 30.5 & 47.75 & 105 & TRUE** & 16 \\
\hline Unidentified Synechococcus sp. 25 & 1 & 1 & 1 & 1 & 29 & 1 & 1 & 1 & 1 & 1 & TRUE** & 14 \\
\hline
\end{tabular}

$$
1
$$




\section{Table 2 (on next page)}

Linear regression analysis of environmental metadata in relation to microbial taxa observed.

Multiple least squares regression analysis at class level taxonomy. Gammproteobacteria, Alphaproteobacteria, \& Betaproteobacteria were abbreviated for space. There were statistically significant relationships with specific taxa and salinity, water temperature, rainfall, and chloride ion concentration. Alpha $=0.10$. 
PeerJ

Manuscript to be reviewed

\begin{tabular}{|c|c|c|c|c|c|c|c|c|}
\hline & Gamma & Flavobacteriia & Acidomicrobiia & Alpha & Beta & Synechococcophycideae & Actinobacteria & Unclassified \\
\hline R-Squared & 0.21 & 0.21 & 0.21 & 0.13 & 0.14 & 0.2 & 0.21 & 0.07 \\
\hline Salinity & $0.017 * *$ & 0.101 & $0.0013 * *$ & $0.0008 * *$ & $0.0005^{* *}$ & NA & $0.051 * *$ & NA \\
\hline Water Temperature & $0.060 * *$ & $0.020 * *$ & NA & NA & NA & $0.001 * *$ & $0.0001 * *$ & NA \\
\hline Chloride & NA & NA & NA & NA & NA & $0.016 * *$ & NA & NA \\
\hline Sulfate & NA & NA & NA & NA & NA & NA & NA & NA \\
\hline Rainfall & NA & NA & NA & NA & NA & NA & NA & $0.0184 * *$ \\
\hline
\end{tabular}

